\title{
Reaching a decision to change vocation: a qualitative study of former priests' experiences
}

\author{
Igor J. Pietkiewicz' ${ }^{1}$
}

Received: 6 April 2015/Accepted: 13 October 2015/Published online: 23 October 2015

(C) The Author(s) 2015. This article is published with open access at Springerlink.com

\begin{abstract}
The aim of this study was to explore experiences of Roman Catholic clergy who relinquish the priesthood. Ten former priests participated in semistructured interviews that were subjected to interpretative phenomenological analysis. Overall, the study found that priests experienced needs and aspirations conflicting with their social role and the expectations made of them. They found making decisions about vocational change frustrating and stressful because of concerns about breaking community norms, fear of social stigma, and disbelief in their ability to cope in lay life. Specific guidelines for supporting priests through counseling psychologists are provided.
\end{abstract}

Résumé. En venir à la décision de changer de vocation : une étude qualitative portant sur les expériences d'anciens prêtres. L'objectif de cette étude était d'explorer les expériences de membres du clergé catholique romain ayant renoncé au sacerdoce. Dix anciens prêtres ont pris part à des entretiens semi-structurés qui ont été soumis à une analyse interprétative phénoménologique. Globalement, l'étude démontre que les prêtres ont éprouvé des besoins et des aspirations qui entraient en conflit avec leur rôle social et avec les attentes placées sur eux. Ils ont trouvé le fait de prendre des décisions à propos de leur réorientation frustrant et stressant, en raison de leurs préoccupations liées au fait de briser les normes de la communauté, de la peur de la stigmatisation sociale, et de leurs doutes quant à leur aptitude à faire face à la vie laïque. Des lignes directrices pour le soutien des prêtres par des psychologues conseillers sont proposées.

Igor J. Pietkiewicz

ipietkiewicz@swps.edu.pl

1 Faculty of Psychology in Katowice, University of Social Sciences \& Humanities, Techników 9, 40-326 Katowice, Poland 
Zusammenfassung. Zur Entscheidung gelangen, den Beruf zu wechseln: Eine qualitative Studie zu den Erfahrungen ehemaliger Priester. Ziel dieser Studie war es, die Erfahrungen römisch-katholischer Priester, welche auf das Priesteramt verzichteten, zu untersuchen. Zehn ehemalige Priester nahmen an halbstrukturierten Interviews teil, welche einer interpretativen phänomenologischen Analyse unterzogen wurden. Insgesamt ergab sich in der vorliegenden Untersuchung, dass die Priester Bedürfnisse und Sehnsüchte erlebten, welche mit ihrer sozialen Rolle und den an sie gestellten Erwartungen in Konflikt standen. Wegen der Besorgnis, gesellschaftliche Normen zu brechen, der Angst vor sozialer Stigmatisierung und aufgrund von Zweifeln an ihrer Fähigkeit, im Laienleben zurechtzukommen, empfanden die Priester Entscheidungen zum Thema Berufswechsel als frustrierend und belastend. Spezifische Leitfaden zur Unterstützung von Priestern durch die Beratung von Psychologen werden bereitgestellt.

Resumen. Toma de decisiones para el cambio vocacional: un estudio cualitativo sobre la experiencia de ex-sacerdotes. El estudio se centró en el caso de los clérigos católicos romanos que abandonan el sacerdocio, analizando sus experiencias. Diez ex-sacerdotes tomaron parte en una serie de entrevistas semiestructuradas, que fueron sometidas a análisis interpretativo fenomenológico. En líneas generales el estudio puso de manifiesto que los clérigos experimentaron necesidades y sentimientos muy enfrentados a su rol social y a lo que la sociedad espera de ellos. La toma de decisión acerca de su cambio vocacional les fue dolorosa y frustrante, en gran medida a causa de sus temores a romper normas prestablecidas, a la estigmatización social, y a ser incapaces de desenvolverse en la vida laica. El trabajo presenta pautas específicas para la ayuda a estos clérigos por parte de psicólogos orientadores.

Keywords Religious priests · Changing profession · Decision-making

\section{Counseling people changing profession}

Work belongs to significant areas of life, and strongly affects how people construct their self-definitions or seek meaning. Individuals often negotiate identity and selfvalue with reference to work activities, as well as membership in work-related groups, such as professional communities or associations (Dutton, Roberts, \& Bednar, 2010). Changing career, on the other hand, can be challenging, not only for people forced to do so (e.g., due to shifting environmental opportunities and demands), but also as a consequence of voluntary choice. Borgen (1997) highlights that not everyone moves from uncertainty to certainty; instead, transition from uncertainty to continued uncertainty is becoming more common. This may result in challenging one's assumptions, undermining personal skills and strengths, feeling distressed, and being unable to move through the decision process or make realistic plans. The impact of self-efficacy (beliefs in one's capacity to successfully perform specific tasks) and outcome expectations (judgment of the likely consequences of performances) on human behavior was stressed long ago (Bandura, 1977). Betz 
(2004) finds that higher self-efficacy is conducive of approach versus avoidance behavior, and may be crucial in the career decision-making process. People with low self-efficacy underestimate their skills, and focus on barriers to what they can do, which often leads to career indecision. Outcome expectations can also impact on career decision-making (Betz \& Voyten, 1997). These expectations may relate to self-efficacy, but there may also be realistic barriers; for instance, due to job-market conditions or discrimination of certain groups. Arthur and Collins (2011) stress that factors such as ethnicity, gender, religion, sexual orientation, age, or social class may affect career opportunities and behavior, and should be taken into consideration in career counseling.

Individuals who change career are encouraged to have counseling to help make sense of their situation, develop new expectations and action plans, broaden their definition of success, redefine areas of personal control, and manage stress. Borgen (1997) says that counselors can help such clients consider challenges, including contextual factors affecting change and, at the same time, empower clients by identifying their resources and assets, and address such problems as self-doubt and overemphasis on weakness. Counselors should also develop their own cultural sensitivity in order to be aware of any factors affecting clients' career choices (Arthur \& Collins, 2011). In some cases, counselors need to support clients in coping with oppressive social conditions. This paper focuses on challenges experienced by Roman Catholic priests, a unique occupational group under-represented in academic literature, who, at some point in their career, struggled with a change of vocation. There is no literature on the effect of contextual factors on the decision-making process of relinquishing the priesthood that could guide counselors' interventions and understanding of clients who are clergy.

\section{Priests as unique clients}

Spiritual guides are highly valued in most societies. Priests are often perceived as having a lifelong 'calling' (Isacco et al., 2014). Pietkiewicz and Bachryj (2014) say that the priesthood involves a specific lifestyle and the language of a valued spiritual leader. Priests are expected to renounce personal ambitions and desires to marry and have children, and dedicate themselves to the Church and its community. Priests often strive to embody religious and moral values in order to be perceived as credible spiritual guides (Baniak, 2001). Pietkiewicz and Bachryj (2014) found that many priests feel they have to remain in a formal role, even in private contexts. In other words, they find it difficult to be off-duty. Specific challenges associated with being a priest include loneliness, struggling with economic and administrative matters, limitations in pastoral work, tense relationships with superiors, as well as positive and negative stereotypes relating to this group. Some priests report unrealistic expectations towards clergy, or prejudice related to scandals in which members of their group are involved, as highly stressful and deepening social distance, and as a disincentive to disclosing one's own problems (Ciarrocchi \& Wicks, 2000; Hoge, 2002; Isacco et al., 2014; Pietkiewicz \& Bachryj, 2014). 
Factors described above can affect priests' well-being. Various studies indicate that priests experience higher levels of psychological distress, depression and burn-out than the general population (Knox, Virginia, \& Lombardo, 2002; Rossetti \& Rhoades, 2013; Virginia 1998). Francis, Louden, and Rutledge (2004) report priests feeling burnt out, frustrated and emotionally drained, which impairs their sense of clear vocational direction, and ability to serve and relate to others. Knox et al. (2005) also show a link between depression and low levels of vocational satisfaction or doubting one's call to ministry.

Distress associated with role-specific challenges, problems with authority structure, and disenchantment with work, fellow priests or the Church's position on theological and/or social issues, may be important factors contributing to the growing rate of leavers reported in literature (Baniak, 2001; DellaCava, 1975). These sociological studies, although quite dated, show that there are priests who cannot reconcile personal needs and aspirations with numerous social expectations associated with the priesthood (e.g., celibacy and obedience) or effectively cope with role-specific challenges or stressors. However, studies also highlight that priesthood involves an ascribed status and is defined as permanent. It is thus inappropriate to talk about 'ex-priests' or 'ex-clergy'. DellaCava (1975) notes that, although just thinking about changing vocation can trigger inner conflicts, psychological analysis of the decision-making process, which could help counselors understand the conflict or contextual factors, is not carried out.

Priests who are exhausted with their role and question their vocation are expected to use religious coping, by consulting a spiritual director, praying more or attending retreats, but not all of them are successful. Some struggle with conflicts for which professional counseling or psychotherapy could be required (Pietkiewicz \& Bachryj, 2014). Despite that, priests tend to underutilize professional services (Knox et al., 2005), using this option as a last resort. Literature therefore recommends actively encouraging the ordained community to use professional services to resolve their problems or symptoms whenever peer support or religious coping fails (Isacco et al., 2014; Pietkiewicz \& Bachryj, 2014). Counselors who are familiar with contextual factors affecting priests' lives can help their clients acknowledge various areas of vulnerability that may have been suppressed or are in conflict. Priests who experience a vocation crisis could also benefit from consulting both spiritual directors and healthcare professionals. However, literature provides limited insight into factors affecting the process of decision-making to relinquish priesthood, perceived gains and consequences. There are no guidelines for clinical or career counselors who are consulted by priests reporting burn-out (or a vocation crisis). This paper aims to fill that gap by identifying contextual factors that affect the decision-making process to relinquish the priesthood, as well as the resulting dilemma and perceived consequences, all of which might need to be addressed during counseling.

In Poland, where this study was held, there are 33,399,328 people baptized in the Catholic Church and 30,481 registered priests (secular and religious), working in 9950 church units (Central Statistical Office, 2012). Candidates for the priesthood are adult men who have graduated from (at least) a secondary school and have discovered a 'calling', and who attend a six-year philosophical theology 
programme. Religious priests attend a novitiate year first, to analyze their motives for becoming a priest, become familiar with a congregation, and receive approval from a superior. On completion of their studies, they receive the sacrament of holy orders incorporating them into the priesthood (perceived as a lifelong service), together with making the vows of obedience and celibacy. Secular priests easily outnumber religious ones (Baniak, 1997). Numbers of secular or religious priests who have left the priesthood are not available to the general public. In 1998, the Association of Married Priests and Their Families was established in Poland to meet the needs for community support and integration of those who left. This study explored experiences of religious priests who left the priesthood, examining challenges and feelings associated with reaching the decision, to provide insight for clinical and job counselors into contextual issues that should be addressed with such clients.

\section{Method}

An idiographic approach was required to identify specific challenges of priests who considered changing vocation. Idiographic studies enable researchers to create provisional hypotheses and prepare ground for further inquiry (Lee \& Tracey, 2005). In this study, I used the interpretative phenomenological analysis (IPA), which synthesizes ideas from phenomenology, hermeneutics, and idiography. It aims to generate rich and detailed descriptions of how individuals experience phenomena under investigation. It employs 'double hermeneutics', in which detailed exploration of how participants make meaning of their world is combined with researchers' attempts to make sense of the participants' meaning (Pietkiewicz \& Smith, 2014; Smith \& Osborn, 2008). IPA studies use a detailed case-by-case analysis of purposely selected, small, homogeneous samples, for whom the research problem is relevant (Smith, Flowers, \& Larkin, 2009). This approach seemed best suited to explore the experiences of leaving the priesthood by former priests, for a greater understanding of their decision-making process and adaptation to lay life. Analyzing these personal perspectives can be valuable to any counseling therapists who provide services to members of this group. Participants in this research defined their own motives for considering a change of vocation, their inner conflicts, and ways of trying to resolve them. They also identified subsequent challenges and factors that helped them re-adapt to lay life. This paper, however, concentrates on analyzing the struggle to make a decision.

\section{Participants}

Participants in this study were ten former religious Roman Catholic priests who had been Salvatorians (www.sds.org), ages 38-52 years. All were Caucasian and Polish, and had graduated from the Higher Theological Seminary, Poland, and acted as priests for 2-12 years. Three came from large cities, five from small towns, and two from rural areas. Three co-habited with a woman, six were in a civil marriage, and only one had received a dispensation from the Holy See to get married in church. 
The ten participants are described in Table 1; their names have been changed to ensure confidentiality.

\section{The researchers}

This paper presents my analysis of qualitative data collected by the interviewer, Mr. Zbigniew Mlak, whom I supervised towards his Masters in psychology, and who himself was previously a religious priest. His background was vital for access and to recruit the sample, as representatives of this group are generally unwilling to talk about their past during interviews (especially recorded) conducted by an outsider. During the analysis, I frequently consulted the interviewer about specific terms used by priests during interviews, and in canon law.

As a psychotherapist and supervisor, I already had some experience in treating and counseling active and former priests, which made me sensitive to certain problems reported by this group, and helped me develop a comprehensive interview protocol for the interviewer to follow. Not being a Catholic, on the other hand, I felt less emotionally involved with the problems discussed during the interviews, which helped me maintain a neutral, etic approach. Discussing data with the interviewer gave us a chance to combine the emic and etic perspectives that are characteristic of an IPA study (Pietkiewicz \& Smith, 2014).

\section{The interview}

The protocol designed by the author included: key areas to be explored, open-ended questions and prompts about participants' religious socialization, motives behind joining the priesthood, their experience in the seminary and pastoral life, circumstances in which they experienced thoughts about living an alternative lay life and their reactions to these thoughts, meanings attributed to leaving the priesthood and their perception of potential consequences, ways of coping with this predicament, how they reached their decision and carried it out, as well as factors that they felt contributed to or impeded successful adaptation. The interviewer covered key areas with every participant and also asked additional questions to explore topics that emerged spontaneously during interviews. At the end of each interview, participants were asked questions to check that the responses were thorough. I also discussed interpretative notes with the interviewer to evaluate my understanding of the content and negotiate its meaning.

\section{Procedure}

This study was conducted in Poland in 2012 and 2013. Following the approval of the local University Committee for Research Ethics, the personal network of the interviewer and a chain sampling technique was used to approach potential candidates. The interviewer knew three of them personally from the Higher Theological Seminar, while others were recommended. The research problem was relevant to all participants-they had all struggled to make a decision about changing their vocation, to relinquish the priesthood, and adapt to lay life. Only ten 
Table 1 Participants $(N=10)$

No. Name Characteristics

1 Ronald Age 52, was born and grew up in a small town. He was a priest for 12 years until 2002. $\mathrm{He}$ worked as a vicar, catechist, and led retreats in Poland and abroad. After a few years, he received a dispensation from celibacy and monastic vows. He had a church wedding with a woman with whom he lives in the countryside, and raises four children (two from her previous relationship). He maintains a good relationship with his family, and occasionally meets friends from the monastery. He works as a translator and interpreter

2 Greg Age 45, was born and grew up in a small town. He spent two years as a priest, and left 17 years before the study. He stayed in the town where he worked as a vicar, and had a civil marriage with a woman, with whom he has a 12-year-old son. He seldom visits the rest of his family and has lost contact with colleagues from his congregation. At the time of the interview, he was working as a company manager

3 Marc Age 44, was born and grew up in a large city. He spent 10 years in the priesthood and held high positions as a teacher. He left the priesthood six years before the interview. $\mathrm{He}$ returned to his home city, where he had a civil marriage with a woman. $\mathrm{He}$ maintains contact with his family, although his parents never fully accepted his decision to leave the priesthood. At the time of the interview, he was working as a teacher and language translator

4 Paul Age 43, was born and grew up in a small town. He was a priest for 11 years, working as a vicar and catechist. He left seven years before the study. He has a wife and two children. He occasionally exchanges emails with his colleagues from the congregation. He works as a sales representative

5 Tom Age 42, was born and grew up in the countryside. He was a priest for two years, working as a vicar. He left the priesthood 12 years before the study. He stayed in the same town and lives with a woman, raising two children. He maintains contact with the rest of his family and occasionally meets his colleagues from the congregation. He works as a sales representative

Age 42, was born and grew up in a large city. He was a priest for almost five years, working as a catechist and in specialized ministries (helping drug addicts). He left the priesthood 12 years before the study. He lives in the countryside with a woman and their four-year-old daughter. He is in contact with the rest of his family and a few congregation peers. He studied further to become a psychologist

Joseph Age 41, was born and grew up in a small town. He spent seven years as a priest, working as a vicar and catechist. He left eight years before the study, at the age of 33. He had a civil marriage with a woman and lives in her city. He still awaits dispensation from the Holy See. He maintains a good relationship with his family and friends from his congregation. He owns his own business

$8 \quad$ Chris

Age 41, was born and grew up in a small town. He spent 10 years in a monastery and two years as a priest. He left the priesthood a few years before the study. He had a civil marriage with a former nun and they have two children. He has no contact with his colleagues and works as a manual worker

Age 39, was born and grew up in a large city. He was a priest for nine years, worked as a catechist and maintained prayer groups. He left five years before the study. He had a civil marriage with a woman with whom he raises a small child. At the time of the interview, he was working as an academic teacher and was involved in NGOs. He maintains rare contacts with priests from his former congregation, or family

10 Stefan Age 38, was born and grew up in the countryside. He spent two years in the priesthood and left seven years before the study. He moved to a village near the town where he worked as a vicar. He lives with a woman and their two-year-old daughter. He maintains good relationships with the rest of his family and a few friends from his congregation. At the time of the interview, he worked as a teacher 
former priests out of 16 contacted by the interviewer agreed to participate. Those who refused said they did not have the time or inclination to revisit painful memories. Those who agreed to participate, however, were willing to share their experiences and openly answered questions, saying that such studies were meaningful and necessary, and they hoped their input would help others with similar problems. Interviews were held at places chosen by the participants, usually at their homes. They were semi-structured and audio-recorded, with durations from 60 to $90 \mathrm{~min}$ long.

\section{Data analysis}

Detailed, verbatim transcriptions were produced for all audio recordings, and these were analyzed in Nvivo10 (computer-assisted qualitative data analysis software). I used the consecutive analytical steps recommended for IPA (Smith et al., 2009). First, I listened to each recording and read the transcripts carefully several times. I used the 'annotation' feature in Nvivo10 to produce extensive notes about the content, language use, and registered my interpretative comments. Then, I categorized the notes into emergent themes, by allocating descriptive labels (nodes). I discussed my coding and interpretations with the interviewer, and, if required, asked him to clarify terms used by the participants. (Certain notions that are obvious for people sharing a religion and profession may be unknown to an outsider.) I followed the same procedure for each interview, and compared the themes between participants. Then, I analyzed connections between themes in each interview and between cases, and grouped themes according to conceptual similarities into superordinate ones and sub-themes. This final report presents an elaboration of the main topics from most interviews.

\section{Results}

Participants discussed their transition from priest to lay life; when they started thinking about a change, their conflicts, worries, and concerns, how they reached a decision, and how they adapted to lay life. A pattern of themes appeared consistently in all interviews. For this paper, I present eight salient themes, listed in Table 2, grouped into three superordinate clusters (heuristic organizing categories), indicating numbers of participants who discussed that theme. These themes do not necessarily represent interdependent entities. In accordance with the IPA principles, I discuss each theme and illustrate it with verbatim excerpts from the interviews.

\section{Living a dilemma}

This cluster included themes about the nature of conflict priests experienced when contemplating a change of vocation, and their doubts and concerns about the potential consequences of relinquishing the priesthood. 
Table 2 Constituent themes grouped into clusters

\begin{tabular}{ll}
\hline $\begin{array}{l}\text { Clusters, superordinate } \\
\text { themes and sub-themes }\end{array}$ & $\begin{array}{l}\text { No. of participants } \\
\text { with theme }\end{array}$ \\
\hline Living a dilemma & 10 \\
1. Contemplating an alternative path & 10 \\
2. Experiencing inner conflicts & 4 \\
Feeling bad for breaking the taboo & 8 \\
Fear of social stigma & 6 \\
Letting others down & 3 \\
Concern with spiritual consequences & 6 \\
Uncertain of one's resources or skills & \\
Attempts to resolve a conflict & 5 \\
3. Escaping threatening thoughts and desires & 5 \\
4. Taking a break & 7 \\
5. Seeking support from others & 3 \\
6. Using professional counseling & \\
Taking a jump & 5 \\
7. Planning a new future & 7 \\
8. Disclosing the decision & \\
\hline
\end{tabular}

\section{Theme 1: contemplating an alternative path}

Participants reported fantasizing about an alternative life to their chosen vocation at different stages of their life. Rob had hesitated about becoming a priest while at the Seminary, but viewed it as a natural reaction. He wished he could have had an honest discussion with someone, saying that conversations with his spiritual father were too superficial.

I still remember the night before taking our vows. We wondered what it would be like to quit. We joked about it, but I realized later that masked our real concerns. [...] Discussions with my spiritual father were usually limited to what book I was reading or when I would stop smoking. - Rob

Greg also had doubts about his vocation during his studies, because of a strong attraction towards a girl he had met. Despite that, like Rob, he was convinced it was already too late, and he tried to conform with the rest of the group.

It was too late to change. Everyone is taking the permanent vows, and so am I.

Things will sort themselves out, I told myself. - Greg

Other participants recalled wondering what it would be like to lead a secular life during their pastoral work. Ronald sincerely enjoyed working as a catechist for many years and never considered a different lifestyle until he met a woman and started longing for a close, intimate relationship. He said "it was no one's fault" for that feeling to appear, as if he needed to excuse himself. Marc shared a similar story. He had not expected this feeling, and felt awkward about breaking his monastic 
vows. He wondered whether to end his relationship, lead a double life, or give up the priesthood.

It is not that I planned this [relationship]. It got more and more intense and then I began to think about renouncing my calling. It was like another step. I had to consider whether to continue... or break up this relationship, and stay in my monastic life, as a priest. - Marc

Joseph, however, associated his conflict with dissatisfaction with assigned activities. He wanted to work in the community, but lack of approval from his superiors frustrated him.

I saw people's poverty and wanted to help them. This is what I really wanted to do after taking my vows but it wasn't compatible with my superiors' will. There was a conflict from the very beginning and I never felt like the right person in the right place. - Joseph

\section{Theme 2: experiencing inner conflicts}

Thoughts about relinquishing the priesthood often led to intense psychological conflicts between participants' private needs or aspirations, and expectations (real or imagined) towards clergy. Rob spoke about his wish to help people as a religious leader and a desire conflicting with the status of a Roman Catholic religious priest; namely, having a family, being a husband and a father. It was not clear, however, why he had chosen to become a priest knowing about these limitations.

People often say: "You like girls and you quit." It wasn't like that in my case. I had always wanted a family - a wife and children. But I also wanted to help others. I thought that by becoming a priest I could devote myself $100 \%$ to serving others. - Rob

Ronald shared similar concerns. He drew much pleasure from his involvement in pastoral activities, but he also wanted a relationship and family life. He knew that giving up the priesthood would lead him to seek alternative ways of working with people.

I knew I had a vocation and that leaving the priesthood would be a great loss. I would lose meaningful things I really enjoyed doing. But I wasn't sure if I could live a celibate life, a religious priest's vocation. - Ronald

Participants often said they felt guilty about breaking the norms of the ordained community, disappointing family or friends, and feared the potential consequences of a decision to quit.

Feeling bad for breaking the taboo Several participants reported intense feelings of guilt and shame for not adhering to the ethos of a religious priest. Marc was torn between his feelings towards a woman, and monastic obligations. He felt ashamed for secretly breaking religious vows, and leading a secret life. 
I felt tremendous remorse every day. I was so ashamed of this... double life. On one hand, I was touching sacred objects and was responsible for the training of future priests, I taught them how they should live, and on the other hand, I was not living according to these principles myself. I was anguished. - Marc

Greg acknowledged dissatisfaction with pastoral life, and discomfort when thinking about the woman he loved, when he was supposed to be concentrating on a ritual or prayer.

This was something I could not reconcile... I was celebrating the holy mass and my thoughts were on Eve. I felt so awkward about this. The idea of leading a double life seemed out of the question. - Greg

Ronald's dilemmas were also of a religious nature. He maintained that he was more concerned about spiritual obligations than social reactions.

My biggest problem was that I had made a promise to God. Throughout my pastoral life I had to deal with public opinion... so, that did not matter so much; but it was important to be fair in front of God. - Ronald

Fear of social stigma Many participants said that leaving the priesthood was associated with social stigma, and said that members of a religious order usually associated those who left with an evil act, backslide, or betrayal.

You could feel some kind of social pressure in this small community. Whenever someone resigned, our teachers or prefects gave sermons or talked about betrayal, spiritual fall, or a victory of weakness over God's will... I thought they would also view me as a traitor if I left. - Jacob

Marc maintained that community members often persuaded such individuals to reconsider their decision and advised them to fight their conflicting desires or aspirations.

If I left, it would be treated as an evil act, and they [peers] would do anything to stop me... from abandoning my chosen path. They said it would make everyone unhappy and I will never find fulfillment... that this is my true path because I have a calling. That I should fight for my calling. - Marc

Jacob, however, recalled his confessor's advice to use professional counseling and "follow his heart" when his conflict led to insomnia and somatic problems. Rob said leaving the priesthood used to be a taboo topic, but nowadays was more frequently discussed.

Believers were also scandalized when priests left the priesthood and established relationships with lay people. Tom, Jacob, and Stefan said that priests held high rank in Poland, and having one in the family was ennobling. Similarly, those that left were seen as shameful, embarrassing, and subjects of gossip.

When I became a priest, there was a difference in people's attitudes... our neighbors, teachers... viewed us with reverence, respect. I worried what people would say about my parents, my mother. Shame and disgrace! He was 
a priest. He left. I thought I should stay for fear of bringing shame on my family. - Jacob

Greg maintained that "according to the teachings of the Church, those who renounce their religious vows will burn in hell." Although this was not his belief, he was concerned about social reactions. Paul observed that anyone who left attracted attention and strong emotions among community members, who compared them to a suicide.

It was viewed as something terrible. How could someone leave? It was a disaster, like being incinerated by the fire of hell... a shock... like a suicide! Paul

This is an interesting metaphor, because social stigma associated with crossing a taboo was often associated with losing love and support from significant others, being condemned and socially excluded by members of the congregation and the general society-in other words, it symbolizes some kind of 'social suicide'. Greg, for instance, talked about becoming an outcast.

Priests who stay do not want any problems. They don't want any contact with me and probably with no one who has done anything similar. This [leaving the priesthood and establishing a relationship] is perceived as scandalizing... cursed by the Church and family, you become an outcast. - Greg

Marc observed that priests who remained in the order avoided contact with those who left, and thought they felt uneasy in case of accidental encounters. It was not clear, however, why they should feel awkward. Jacob hypothesized that his vocation conflict may trigger similar concerns in friends who preferred not to confront such disturbing feelings or doubts.

Rob was also afraid of becoming an object of prejudice, derision, and ridicule. He imagined situations in which he would feel embarrassed or discriminated for his past.

I worried that people would recognize me, point at me, laugh or shout offensive things at me. I also worried that being an ex-priest would affect my job prospects; no one would want such a person... I also thought... what if I fall in love with a girl and when she finds out I was a priest, she rejects me.Rob

Because of the scandal attributed to leaving the priesthood, Church authorities expected leavers to move to another district, and keep a low-profile. Participants said this was crucial if they ever wanted to apply for a dispensation from monastic vows (including celibacy).

Letting others down Most participants were concerned about the reaction of family, friends, and the religious community to a decision about leaving the order. Tom felt guilty because he perceived his status as a "source of happiness, joy, and honor" for his family, and was convinced that leaving the order would hurt many people, especially his parents, who would be unable to accept it. Marc also worried 
how his family would react. He imagined their disappointment and public humiliation.

I imagined they would be ashamed that their son, who was a priest, is suddenly not a priest anymore. What would neighbors and relatives say? How could they socialize with people in that environment? - Marc.

Joseph was convinced that his family would never accept him leaving the order. He worried about depriving them of social prestige and embarrassing them in a small community.

My family is very religious and it was such an honor for them when I became a priest. Taking that away from them was so hard. I also come from a relatively small town, where everyone knows one another. So, it would be an additional burden for them if people start to gossip. - Joseph

Jacob had a similar dilemma with his mother, whom he described as controlling, manipulative, and possessive. He said he joined the Seminary "to run away from her and relationships with women." He worried that she would reject him for leaving the order, not only because it deprived her of the privilege of a son who was a priest, but also because another woman was involved in the decision. He said:

These were the 90s and priests were important members of society. She was so proud-her only child was a priest. I thought it would break her heart... especially doing that for another woman. - Jacob

Marc's dilemma was related to the anticipated reaction of his superiors. They provided his education in Rome and had strong hopes and expectations of him. Marc often heard he was "the future of his order" and was extremely sorry to disappoint them. Whereas most accounts referred to letting others down, only Roland mentioned a reverse situation. While being a priest he fell in love with a woman who already had two children from a previous marriage. He established a warm and close relationship with all three of them and worried that separating from these children would traumatize them.

It was such a strong conflict. I told myself that, if I refrain, I would hurt both her and the two children, because we had become so close. They had already suffered so much and needed a father so badly. I feared I would be abandoning three people I loved. - Ronald

Concern with spiritual consequences Besides the stress and perceived consequences of renouncing religious vows, participants also considered how their spiritual life would change. Former priests cannot participate in religious sacraments until they have been granted a dispensation from religious vows. Joseph said this was one of the most painful losses for a religious person.

It takes years to get a dispensation from the Holy See, if ever. Until then you cannot celebrate the sacraments. I had to take that into account...We had a 
civil marriage but cannot get married in Church, or receive Holy Communion.

It is painful because we are still very religious. - Joseph

Ronald recalled how important it was for him to re-establish his relationship with God and the Church, and took immediate action to apply for a dispensation once he left. He said he really appreciated being able to get actively involved in the religious life of the parish.

Uncertain of one's resources or skills Economic dependence on the religious order, decreased sense of self-efficacy and trust in one's own skills were possible barriers to any alternatives to religious vocation. Joseph said that religious priests took vows of obedience and poverty, and, like his peers, he had relied completely on the order and had no savings of his own. He was afraid of not having assets and experience necessary to survive in lay life.

I was certainly scared about how I would manage. While you are in the order, you have support... financial, economic... everything is provided for you. I was aware that if I leave... if you have a theological education background, you can't use it to find a job. You don't have many practical skills either. Joseph

Rob thought his experience was inapplicable in the job market and might even be an obstacle to finding work. He thought potential employers might discriminate against him for his past.

Who would hire an ex-priest? I can only teach catechesis, but who in this town wants an ex-priest to do that? They can hire priests, nuns, or lay catechists. An ex-priest... if he has decided to leave, that means he must be at odds with the Church. So, what other options do I have? I can be a manual worker, supermarket cashier or a warehouse clerk. - Rob

Marc described his life in terms of changing one form of dependence for another. He referred to being reliant on his parents until he joined the order. He also compared the Church to a mother who sustains her children. He knew that renouncing the congregation would inevitably make him economically dependent on someone else - the woman with whom he established a relationship. Marc later found that being unable to provide for the family was frustrating, conflicted with his ideal to be a breadwinner, and subsequently affected how he felt as a man.

I had nothing; I had no job, and knew I would have to count on her [girlfriend]. Becoming so dependent again was very frustrating. I did not feel like a man, an equal partner, who can provide for the home, and take care of his family. - Mark

\section{Attempts to resolve a conflict}

This cluster describes ways in which priests tried to cope with their conflicting desires and needs. Topics classified herein refer to suppressing thoughts and desires, taking a break, and using social support and/or professional help. 


\section{Theme 3: escaping threatening thoughts and desires}

As noted earlier, thoughts, aspirations, and desires conflicting with a chosen vocation often produced inner conflicts that could lead to intense stress. Marc said no matter how much he tried not to think about having an intimate relationship or children, the idea often spontaneously returned when he met couples and conferred baptism or a marriage. He said he "fantasized how it would feel to stand in that man's place and enjoy that moment." Jacob and Rob tried to suppress their conflicting thoughts and desires by throwing themselves into work and focusing on other activities.

I became a workaholic to escape my dilemmas. I was very active, I read a lot, and got involved in different projects. I did not break any rules. There were no women, alcohol, or drugs, but my sexual tension was growing. Sometimes I engaged in autoerotic behavior but, because it was a sin, I felt guilty. When I stopped being occupied with something, my conflicts exploded double strength. - Jacob

Rob immersed himself in pastoral service for drug addicts. He realized that "there was nothing but work for many years and, although it was enjoyable to some degree, it led to complete burn-out." He thinks this condition resulted from having his own needs for a close relationship frustrated. Ronald and Marc described similar scenarios of falling in love with a woman and trying to fight their feelings. Both men tried to run away from the objects of their desire, hoping it would allow them to control their state of mind. Ronald referred to values of the ordained community to rationalize his coping strategies learnt during the socialization process.

I fell in love with a woman and there were two options for a priest. A common solution, which they taught us at the Seminary, was not to give into that feeling. You have to fight it, suppress it, because we are destined for a higher purpose. Earthly love is so mundane in comparison to that purpose. So my first thought was: how to get rid of that feeling? I asked for a transfer. I just wanted to escape, because that is what my common sense and conscience dictated. I wanted to be sent far away. - Ronald

Marc found the same strategy inefficient. He experienced intense doubts, hesitation, and changed his mind several times before he finally decided to "cross to the other side."

This process of crossing to the other side, I mean leaving the priesthood, lasted a year and a half. I was actually living with the woman who later became my wife. I walked away [from her] and came back. I had moral dilemmas, went away and returned, went away and returned. I tried to end the relationship and asked my superiors to send me on a mission to Mexico. I wasn't there for long, a month perhaps. I knew it was a test for me and I could not make it. - Marc 


\section{Theme 4: taking a break}

Five participants asked their superiors for a longer break to reflect upon life and vocation. Joseph justified it by saying he had a "vocation problem" and wanted time to seek answers to questions bothering him. Rob also intended to make his final decision after a year's break during which he was allowed to live outside the order, but keep his monastic vows. He thought it was important to live outside the monastery to experience how lay people lived their lives, despite the risk of indulging in the mundane world.

The canonical law says that we all have a right to such a break. There is nothing wrong with that. It is similar to how teachers take their sabbatical to rest. They suggested I join the Benedictines, but I did not think it was a good idea. If you want to consider such a decision [to leave the priesthood], you should really see how people live in the outside world. Some say the outside world would consume you and you would never come back, but I don't think that is true. - Rob

Ronald asked for a transfer to a harsh contemplative order, to pray in solitude for six months. He said he wanted to spend time in retreat and silence to "fight the feeling of attraction" towards the woman for whom he was considering leaving the priesthood. Stefan tried a similar solution and went on retreat followed by a mission abroad. He referred to that experience as "being suspended in a void" and did not enjoy it. He realized that he was not comfortable in the solitude with which he associated the priesthood, and decided to change his path.

\section{Theme 5: seeking support from others}

Most participants shared their concerns with others (e.g., colleagues, superiors, lay partners or friends) when seeking emotional support or looking for help in resolving their conflict. Some found this strategy helpful, but others reported dissatisfaction and disappointment. Joseph, for instance, discussed his dilemma with an elder priest from his congregation, and found his accepting attitude very supportive.

I used to talk with my co-brother; I still recall him telling me: "Remember, the most important thing is to be happy. So, if you feel that you should leave, just do it." - Joseph

At the Seminary, Rob found the support of the spiritual father who was assigned to him to be unsatisfactory. He was afraid of being judged, which blocked him from opening up. He said: "I was afraid he would tell me I was unsuitable to become a priest." Years later he found an experienced guide from the USA, with whom he discussed his vocational problems and who encouraged him to use professional counseling. He consulted that psychologist during his break, and also attended retreats at the Franciscan order where he shared his concerns with elderly priests, and appreciated that they never influenced his decision one way or another. 
I had my cell there and I could talk to the Franciscans. They often said I had to make my own decision. They could share their perspective... why they thought I decided to go to a Seminary, why I had thoughts about leaving; but the decision was mine. - Rob

While Rob appreciated support from congregation members, and the autonomy to make his independent choice, the expectations of Stefan and Tom towards community members were unclear and ambivalent. Stefan wanted a decision to be made for him and felt frustrated with the "freedom of choice" he received. He experienced the autonomy to make a responsible decision as abandonment.

I wanted them to assess my situation, the purpose of my life... what I should do, where I should work. I wanted someone to help me keep... re-discover my vocation. I wanted to be active and not on retreat. I expected them to help me, give me meaning, take me to some parishes where I could be fulfilled. But they said nothing. - Stefan

Although he wanted to leave the order to follow his own aspirations and needs, Stefan was hesitant about the consequences of his choice and wanted others to control his life, possibly making them responsible for his (un)happiness. Tom expressed a similar attitude. It seems that he intended to resolve his conflict by trying to provoke his superiors to make the decision for him. He was bitter about the experience and disappointed with congregation members.

I talked to them [superiors] a number of times. They knew I was emotionally involved with this woman. The main superior knew about it but did nothing. He just waited. He washed his hands of me. I think he was just waiting for me to resign. - Tom

\section{Theme 6: using professional counseling}

Only Jacob, Greg, and Rob said they had used professional counseling to deal with their problems. Jacob said his spiritual guide encouraged him to consult a psychologist, because his vocational conflict had triggered chronic symptoms of anxiety, shortness of breath, and sleeplessness.

I couldn't sleep because of this internal battle; just sleeping for half an hour before waking with intrusive thoughts... I had panic attacks and difficulty breathing. When I joined the order we were given the cardinal costume, and received good feedback from our neighbors. I had an adrenaline rush.... Later on, I asked myself-why am I here? I wondered if this was the right path because... before I enrolled in the Seminary, I had met this girl who is now my wife. - Jacob

Jacob felt that priests' attitudes to professional counseling or psychotherapy varied between acceptance, caution or skepticism, and that antagonism towards it increases when those who use it finally leave the priesthood. Therapy is then seen as a tool leading to "opposing God's will." Jacob maintained that those who used professional services were likely to keep it secret. 
The attitude of priests to visiting therapists is twofold. Some say it can be beneficial, and helps with the decision about whether the priesthood is the right path. Others undermine the value of therapy, ridicule it, negate it. They didn't threaten us with hell, but they thought that if one left the priesthood after using therapy, this was opposing God's will. You should fight spiritually and not rely on uncertain tools. I knew a few priests who consulted therapists, but they would not normally disclose that fact. - Jacob

Greg also consulted a therapist. He appreciated being asked open questions that helped him see his situation from various angles and reflect upon the potential consequences of each choice. Therapy provided the opportunity to verbalize his conflicting thoughts and emotions, which lessened his stress. Greg maintained that priests who were not "brave enough to make their decision are likely to seek solace by drinking alcohol."

I really appreciate not being told what to do but simply being asked questions, so I could express my doubts, say how I feel. These questions stimulated... I felt unable to escape. She confronted me with the fact that I was between a rock and a hard place, and I had to make a choice. - Greg

\section{Taking a jump}

This cluster includes themes about making the final decision to leave the priesthood. Participants talked about planning new futures and disclosing their decision to others.

\section{Theme 7: planning a new future}

All our participants tried to resolve their inner conflict by planning a new, lay, life. Paul suspected that the fact that he was in a relationship and about to become a father would shock the community.

The birth of my daughter provided the impulse to plan a new future. I decided to use the spring break, when children are off school and priests also take holidays. I planned to leave then to avoid a scandal. - Paul

Five participants expressed their concern about economic situations and living conditions. Tom said that he was not used to worrying about accommodation and food. He associated the upcoming transition with new challenges, especially as he did not want to return to his parents' home.

Money is the biggest problem if you leave. In the order, we don't have to worry about food or a place to sleep. Outside, your life turns upside down and you start worrying about these things. I do not think any priest would want to go back to his parents. You simply need to find accommodation and work. That is a real problem and you need to prepare yourself, somehow. - Tom

Paul said the situation was easier if one could rely upon someone's support, such as "a woman or a friend who will give you food and let you crash overnight." 
Otherwise, he thought it was risky to leave without anticipating problems and reflecting upon practical things. Jacob confirmed that the transition involved certain investments. He had to move to a different town, buy furniture and new clothes. Rob considered acquiring occupational skills and developing new networks, saying that it was crucial to develop self-confidence and experience by enrolling in courses and learning a new occupation to feel more secure and cope better.

I had to prepare myself financially and occupationally. You can enroll in courses, learn a new occupation, or find a job before you leave. It is about financial security... which provides mental security. - Rob.

\section{Theme 8: disclosing the decision}

Participants informed their superiors, family, and friends about the decision to leave the priesthood in different ways. Some had previously revealed their concerns and sought external support (see theme 5), while others said nothing until they had reached a decision and simply notified others about their choice. Rob, for instance, had previously shared his vocation-associated concerns with a lay friend who was also a therapist, and who supported him in decision-making.

We were close friends and I could discuss these topics with him. He was very religious but also very clear-minded. He was the first person to hear about my decision to leave. Then, I informed people in the parishes. I went to the Provincial Superior and my parents. I didn't just pack and leave but I wanted to inform everyone. - Rob

Paul discussed his plans only with his partner and wanted to notify everyone on the day he left the order. He was afraid of negative reactions and letting someone sow uncertainty in him.

I decided to inform my superiors and everyone else at the last minute. I only talked to my partner, now my wife, about it. The family did not know either. I was surprised by their reactions. My parents were sad, and worried I would find it difficult to cope as a lay person. My superiors were shocked. The bishop even organized a devotion to propitiate for my sins. - Paul

What Paul mentioned jokingly about propitiating for his sins was an additional burden. Rather than experiencing the devotion organized for him as support, it brought home to him the heavy spiritual consequences of his actions.

Ronald chose a unique way to communicate his revelation. He invited his superior on a trip to the mountains to disclose his situation. He said he needed that informal setting to feel more confident. It may also have given him some sense of control. He was apprehensive about the expected feedback, and although his superior did not like Ronald's choice, he accepted his mature, autonomous decision. Later, when Ronald told his mother, he found her words: "do whatever makes you happy" very supportive. Greg, who had taken a break, said how important it was to inform his superiors officially about his intentions, in order to avoid misconceptions and faulty expectations; but, even so, he was excluded from the order. 
I wanted to clarify things to avoid anyone looking for me or awaiting my return. I did everything officially. I went back to the town where I had worked as a vicar, visited the rector and told him I was leaving. When I got married, I sent my marriage certificate to the provincial superior so that he did not find out from anyone else. He immediately sent me the official document saying I was cursed by the Church. - Greg

Like Paul, Greg seemed indifferent to the reference to being cursed, with an attempt at ridicule. However, it probably masked deeper feelings of regret, guilt, and anger associated with being punished for a decision to leave in favor of personal goals and needs.

\section{Discussion}

This appears to be the first psychological study exploring the experience of changing vocation by Roman Catholic priests, which highlights contextual factors and intra-psychic conflicts. The aim of this paper was to inform clinical and job counselors or psychotherapists about specific challenges that clients from that group may encounter, as well as to provide practical guidelines regarding areas to explore during therapy.

Studies show that clergy generally report high levels of depression and burn-out (Francis et al., 2004; Knox et al., 2002; Rossetti \& Rhoades, 2013; Virginia 1998), which may result from a variety of difficulties, described by numerous authors (Ciarrocchi \& Wicks, 2000; Hoge, 2002; Pietkiewicz \& Bachryj, 2014). These challenges may lead some priests to consider changing vocation (Baniak, 2001; DellaCava, 1975). DellaCava (1975) notes that just thinking about leaving the priesthood may produce an inner conflict, which Kreiner, Hollensbe, and Sheep (2006) explain in terms of tension between personal and social identities. However, the nature of that conflict has not been thoroughly explored from a psychological perspective. This analysis shows that the transition to lay life is a significant challenge from the psychodynamic perspective. Leaving the priesthood reactivated in some participants separation conflicts characteristic of adolescence, which was evident in the way they experienced dependence from their religious order and established autonomy. I suspect that the same conflicts may also have played an important role in their original decision to join the priesthood. This, however, would require further investigation.

Priests who join higher theological seminaries immediately upon leaving school may not have had the chance to build autonomy from parents, develop financial independence or job experience. Their motives to become priests may be complex and involve both spiritual and non-spiritual reasons. The latter may include meeting the expectations of significant others, gaining social prestige and appreciation, or trying to escape developmental challenges of early adulthood, including moving out of the family home, establishing intimate relationships, pursuing careers or entering the job market. Some individuals may just replace one form of dependence (the family home) for another (the seminary). The 
Church structure can replace the family and be experienced as a sustaining, yet controlling and demanding parent; one that demands obedience, and encourages intellectual and spiritual, but not sexual, growth. In some families, parents may encourage their sons to become priests for reasons other than social prestige. If parents have difficulties accepting their son's developing autonomy and sexuality, his leaning towards a lifestyle involving celibacy and sexual abstinence can evoke additional approval. All these complicated issues and motives for joining the clergy in the first place are likely to resurface when a decision to leave is considered.

Our participants found that staying in the order, and complying with endorsed and internalized norms associated with having taken vows, conflicted with their alternative needs or aspirations. Although they felt unable to explore and express their needs for autonomy or sexuality, igniting frustration and a desire to leave, they also hesitated, fearing spiritual and social consequences. That is why I think this situation metaphorically represents the process of young adults trying to develop autonomy from their parents, and leave home, triggering a variety of adolescent conflicts. Doubts may arise, such as: What happens if I break home rules? If I decide to leave, can I return if necessary? Will they still love and support me, if I disagree with them and make my own choices? Can I survive on my own? The participants were frequently concerned about losing the love and support of their family if they left the priesthood and its ennobling social position. Grosch and Olsen (2000) observe that priests may invalidate their own needs and become attentive to the needs of others, thus repeating their childhood experiences. However, ambiguous feelings about autonomy and satisfying one's own desires may also be associated with sexuality.

Most participants left the priesthood for a woman, and worried about social response. Metaphorically speaking, they were concerned how parents and friends would react to the girlfriend, but no participant reported wondering about any conflicts his partner might experience, what his status meant for her, how she felt about being chosen by a priest and having an intimate relationship with him, and how she experienced him renouncing his vows for her. None of them voiced doubt about whether he was planning his life with the right person, or if their relationship would survive. While most participants referred to sexuality in a superficial way, using abstract expressions such as "I wished to fulfil myself as a partner or parent," they seemed uneasy about discussing sexual attraction, desire, or arousal. It is possible that the interviewer's own background as a former priest made him identify with study participants, adopt similar discourse, and hindered him from asking direct, confronting questions. On the other hand, difficulty in discussing sexuality openly can also be because priests and monks are expected to be nonsexual and pure (Pietkiewicz \& Bachryj, 2014). On the other hand, intimate relationships between spiritual fathers and lay practitioners are perceived as shocking. I believe that the intense social reaction is because an unconscious incest taboo has been triggered. How priests and their partners experience their relationship and the transition to lay life, however, requires further investigation. 


\section{Implications for counseling psychologists}

The results section of this study indicate areas that counseling psychologists should consider and explore with clients who are priests reporting dissatisfaction with their role and/or considering changing vocation. If the costs of celibacy and loneliness outweigh the role-satisfaction associated with being a religious leader, according to Schoenherr and Greeley (1974), priests (especially young ones) are more likely to quit. This study, however, indicates a greater complexity of factors affecting decision-making, e.g., conscious and unconscious conflicts associated with autonomy. Psychologists should therefore analyze the history of clients' religious socialization, the meaning attributed to one's 'calling,' reasons for considering vocational change and perceived consequences. They should explore clients' earlier experiences with separation: how they tried to express autonomy, what response it evoked and what that meant for them. This study indicates that it may be necessary to discuss priests' expectations towards peers and superiors with reference to decision-making, because some of them may develop unrealistic expectations or try to defer control and responsibility onto others, probably due to conflicting feelings about autonomy.

Counseling psychologists should analyze the impact of personal and contextual factors on decision-making and career development (Arthur \& Collins, 2011; Borgen, 1997). Participants in this study frequently experienced shame, guilt, and stigma-related fear. They often expected a negative response from other priests or lay people, and were concerned about losing support and becoming an object of scandal or ridicule. The anticipated reaction was not always the actual one. Participants' expectations about rejection partially reflected general attitudes of the community towards leavers, but may also have been a projection of their own internalized stigma ascribed with renouncing the holy service.

Borgen (1997) says that counseling sessions can provide individuals changing vocation with an opportunity to express emotions and discuss anticipated consequences. It may be beneficial to address priests' concerns and meaning attributed to leavers. The risk of being shunned should be addressed and clients should be encouraged to develop new social networks, especially because priests who leave and request a dispensation are expected to relocate to avoid a scandal. Some will also find it beneficial to redefine renouncing the priesthood as a valuable experience in their spiritual or personal development, instead of seeing it as a downfall. Therapists can also discuss or even role-play with clients possible reactions to prejudice or discrimination, making a disclosure during a job interview, etc. McAuliffe (1992) finds that vicarious learning is highly beneficial, such as presenting examples of success stories in individual or group settings. Establishing support groups moderated by those who have successfully managed to make the transition to lay life can therefore be considered.

Another potential area for therapeutic work involves the perception of one's resources, self-esteem and self-efficacy. Betz and Voyten (1997) and Betz (2004) notes that those who trust their skills and have better outcome expectations reach career decisions more easily. Psychologists can help priests who consider leaving to assess their own skills and assets realistically, and plan for new qualifications, job- 
hunting, and further career development. Borgen (1997) encourages the formation of immediate, midrange, and long-term action plans. Some priests may need to acknowledge any soft skills developed during pastoral service that can be applied in other professional contexts. For that purpose, simple cognitive-behavioral techniques, such as encouraging clients to name their past achievements, can help (McAuliffe, 1992).

Whereas feelings of loneliness or frustration reported by priests in this and other studies (Baniak, 2001; Hoge, 2002; Pietkiewicz \& Bachryj, 2014) may contribute to considering a vocational change, counseling psychologists should explore personal and cultural factors that may affect why their clients feel lonely or burnt-out. For example, Pietkiewicz and Bachryj (2014) highlight the pathoplastic aspect of religious leaders' culture, in which difficulties establishing satisfactory relationships and friendships due to personality factors can be rationalized in terms of celibacy or group norms. If that is true, many who leave the priesthood would continue to feel lonely and dissatisfied with personal relationships unless the underlying problem with developing satisfactory bonds is properly addressed during treatment. Consolers should investigate the interplay of community norms and personality factors to determine suitable interventions.

Finally, it should be stressed that considering breaking, or actually breaking, the norms of the religious community often evokes frustration, guilt, or self-reproach in clients. Not only do they expect critique and punishment from their community for crossing the taboo, they may anticipate similar reactions from the therapist. This may be why priests tend to avoid disclosing personal problems, and underutilize professional help. Studies show that they are concerned about confidentiality, want to maintain a positive image of themselves and of the Church, or fear social stigma (Isacco et al., 2014; Pietkiewicz \& Bachryj, 2014). They may project their harsh superego on the counselor and anticipate criticism or rejection. Practitioners with the same religious background as a client risk identifying themselves with these shared norms, which can lead to loss of flexibility to explore sensitive issues, taking things for granted, or difficulty questioning social axioms. So, therapists counseling priests should be mindful about whether or not their own views on priesthood, religiousness, human sexuality and related subjects (e.g., sexual abstinence, premarital sex, adultery, masturbation, homosexuality) are consistent with religious principles endorsed and internalized by their clients. This may hinder therapists from maintaining a neutral, therapeutic stance. Furthermore, treating a spiritual leader from the same religious tradition, which involves a symbolic transposition of roles, may produce an additional challenge for psychologists (Pietkiewicz \& Bachryj, 2014). When a client is perceived (due to cultural reasons) as an authority, treating him is likely to resemble treating one's own parent, and may trigger a variety of feelings in the counselor. Exploring countertransference and one's own biases in these areas during supervision would be crucial.

\section{Limitations and further direction}

This study offers insight into difficulties experienced by Roman Catholic priests who consider changing vocation. It is crucial that anyone who counsels such priests 
understands the nature of their conflict, as well as contextual factors affecting decision-making. Although this is an idiographic study with a small and homogenous sample, such an approach also provides a provisional hypothesis for counseling (Lee \& Tracey, 2005). However, further investigation is required to compare these results with other samples. For example, this sample was limited to priests who had relinquished the priesthood and managed to establish alternative careers. A comparative study on priests who made the decision to stay in an order or to lead a double life would be useful to understand how they managed their conflicting needs or how they sought a compromise. How the decision to relinquish the priesthood affected social relationships and support also justifies further elaboration. Exploration of factors that contribute to or hinder effective adaptation to lay life may also help counseling psychologists plan interventions and support programs. Lastly, comparative studies are required to determine how cultural contexts affect results. For example, attitudes towards priests leaving the priesthood in general society and the ordained community may differ depending on the context. Investigation would be useful among secular priests, as well as religious priests affiliated with different orders (e.g., Dominicans, Franciscans, Jesuits, etc.). Crosscultural studies would reveal how the culture in more secular counties, compared to ones more dominated by the Roman Catholic Church, affect these problems. There is also no evidence about reactions to priests and monks who change vocation in other non-Catholic religious communities and how that affects their adaptation. Because shunning religious community members can disrupt their existing networks of social support and threaten health (Pietkiewicz, 2014), further investigation is required regarding how leavers adapt, what coping strategies they use and how they utilize help.

\section{Conclusion}

Literature shows that Roman Catholic priests report significantly higher levels of depression and burn-out compared to the general population. Despite the growing number of clergy who decide to leave the priesthood, there is a gap in psychological research regarding contextual factors affecting the decision. This is the first study to explore priests' dilemmas associated with changing vocation, and meanings ascribed to relinquishing the priesthood. An IPA was used to explore former priests' experiences associated with the transition to lay life, which revealed significant intra-psychic conflicts associated with the decision to leave. It is recommended that counseling psychologists explore these issues with reference to clients' earlier experiences associated with separation and autonomy. They should also explore the impact of personal and cultural factors on the decision to leave, provide emotional support, and help clients build strategic plans. The counseling of Roman Catholic clergy who consider relinquishing the priesthood by Roman Catholic psychologists may also produce specific challenges that are experienced in countertransference. 
Open Access This article is distributed under the terms of the Creative Commons Attribution 4.0 International License (http://creativecommons.org/licenses/by/4.0/), which permits unrestricted use, distribution, and reproduction in any medium, provided you give appropriate credit to the original author(s) and the source, provide a link to the Creative Commons license, and indicate if changes were made.

\section{References}

Arthur, N., \& Collins, S. (2011). Infusing culture in career counseling. Journal of Employment Counseling, 48, 147-149. doi:10.1002/j.2161-1920.2011.tb01098.x.

Bandura, A. (1977). Self-efficacy: Toward a unifying theory of behavioral change. Psychological Review, $84,191-215$.

Baniak, J. (1997). Dynamika powołań kapłańskich i zakonnych $w$ Kościele rzymskokatolickim w Polsce 1900-1994. Studium socjograficzne [The dynamics of vocations in the Roman Catholic Church in Poland, 1900-1994. A sociographic study]. Kraków, Poland: Nomos.

Baniak, J. (2001). Rezygnacja $z$ kapłaństwa $i$ wybór życia małzeńsko-rodzinnego przez księży rzymskokatolickich $w$ Polsce. Studium socjologiczne [Leaving the priesthood and the choice of married and family life by Roman Catholic priests in Poland. A sociological study]. Kraków, Poland: Nomos.

Betz, N. E. (2004). Contributions of self-efficacy theory to career counseling. A personal perspective. The Career Development Quarterly, 52, 340-353. doi:10.1002/j.2161-0045.2004.tb00950.x.

Betz, N. E., \& Voyten, K. K. (1997). Efficacy and outcome expectations influence career exploration and decidedness. Career Development Quarterly, 46(2), 179-189.

Borgen, W. A. (1997). People caught in changing career opportunities: A counseling process. Journal of Employment Counseling, 34, 133-143. doi:10.1002/j.2161-1920.1997.tb00990.x.

Central Statistical Office. (2012). Statistical yearbook of the Republic of Poland: 2012. Warsaw, Poland: Central Statistical Office.

Ciarrocchi, J. W., \& Wicks, R. J. (2000). Psychotherapy with priests, Protestant clergy, and Catholic religious: A practical guide. Madison, CT: Psychosocial Press.

DellaCava, F. A. (1975). Becoming an ex-priest: The process of leaving a high commitment status. Sociological Inquiry, 45, 41-49. doi:10.1111/j.1475-682X.1975.tb00348.x.

Dutton, J. E., Roberts, L. M., \& Bednar, J. (2010). Pathways for positive identity construction at work: Four types of positive identity and the building of social resources. Academy of Management Review, 35, 265-293. doi:10.5465/AMR.2010.48463334.

Francis, L. J., Louden, S. H., \& Rutledge, C. J. F. (2004). Burnout among Roman Catholic parochial clergy in England and Wales: Myth or reality? Review of Religious Research, 46, 5-19. doi:10.2307/ 3512249.

Grosch, W. N., \& Olsen, D. C. (2000). Clergy burnout: An integrative approach. Journal of Clinical Psychology, 56, 619-632. doi:10.1002/(SICI)1097-4679(200005)56:5<619::AID-JCLP4>3.0.CO;2-2.

Hoge, D. R. (2002). The first five years of the priesthood: A study of newly ordained Catholic priests. Collegeville, MN: Liturgical Press.

Isacco, A., Sahker, E., Hamilton, D., Mannarino, M. B., Sim, W., \& St Jean, M. (2014). A qualitative study of mental health help-seeking among Catholic priests. Mental Health, Religion \& Culture., 17, 741-757. doi:10.1080/13674676.2014.910759.

Knox, S., Virginia, S. G., \& Lombardo, J. P. (2002). Depression and anxiety in Roman Catholic secular clergy. Pastoral Psychology, 50, 345-358. doi:10.1023/A:1014461603872.

Knox, S., Virginia, S. G., Thull, J., \& Lombardo, J. P. (2005). Depression and contributors to vocational satisfaction in Roman Catholic secular clergy. Pastoral Psychology, 54, 139-155. doi:10.1007/ s11089-005-6199-1.

Kreiner, G. E., Hollensbe, E. C., \& Sheep, M. L. (2006). Where is the "me" among the "we"? Identity work and the search for optimal balance. Academy of Management Review, 49(5), 1031-1057.

Lee, D., \& Tracey, T. J. (2005). Incorporating idiographic approaches into multicultural counseling research and practice. Journal of Multicultural Counseling and Development, 33, 66-80. doi:10. 1002/j.2161-1912.2005.tb00006.x.

McAuliffe, G. J. (1992). Assessing and changing career decision-making self-efficacy expectations. Journal of Career Development, 19, 25-36. doi:10.1007/BF01323002. 
Pietkiewicz, I. J. (2014). Salutary, pathogenic, and pathoplastic aspects of the Jehovah's Witness culture. Journal of Family Studies, 20, 148-165. doi:10.5172/jfs.2014.488.

Pietkiewicz, I., \& Bachryj, D. (2014). Help-seeking attitudes and coping strategies among Roman Catholic secular clergy. Psychology of Religion \& Spirituality. doi:10.1037/re10000019.

Pietkiewicz, I. J., \& Smith, J. A. (2014). A practical guide to using interpretative phenomenological analysis in qualitative research psychology. Psychological Journal, 20, 7-14. doi:10.14691/CPPJ. 20.1.7.

Rossetti, S. J., \& Rhoades, C. J. (2013). Burnout in Catholic clergy: A predictive model using psychological and spiritual variables. Psychology of Religion and Spirituality, 5, 335-341. doi:10. 1037/a0033639.

Schoenherr, R. A., \& Greeley, A. M. (1974). Role commitment processes and the American Catholic priesthood. American Sociological Review, 39(3), 407-426.

Smith, J. A., Flowers, P., \& Larkin, M. (2009). Interpretative phenomenological analysis: Theory, method and research. London: Sage.

Smith, J. A., \& Osborn, M. (2008). Interpretative phenomenological analysis. In J. Smith (Ed.), Qualitative psychology: A practical guide to research methods (pp. 53-80). London: Sage.

Virginia, S. G. (1998). Burnout and depression among Roman Catholic secular, religious, and monastic clergy. Pastoral Psychology, 47, 49-67. doi:10.1023/A:1022944830045. 